\title{
Pengaruh Lama Perkecambahan terhadap Karakteristik Fisik, Kimia dan Fungsional Tepung Kecambah Jagung Pulut (Zea mays ceratina L.)
}

\section{Effects of Germination Time on Physical, Chemical and Functional Characteristics of a Germinated Waxy Corn Flour (Zea mays ceratina L.)}

\author{
Gery Hartawan $^{1}$, Ni Wayan Wisaniyasa ${ }^{* *}$, A.A.I. Sri Wiadnyani ${ }^{1}$ \\ Program Studi Teknologi Pangan, Fakultas Teknologi Pertanian, \\ Universitas Udayana, Kampus Bukit Jimbaran, Badung-Bali \\ Penulis korespondensi: Wisaniyasa, Email: wisaniyasa@unud.ac.id
}

\begin{abstract}
This study aims to know the effect of time on the germinated waxy corn flour characteristics and to know which time that can produce a germinated waxy corn flour with the best characteristics. This research used a Complete Randomized Design with a different germination time as the treatment, which is 0 hour, 24 hour, 36 hour and 48 hour. The experimentation was repeated 4 times resulting 16 experimental units. The data obtained were analyzed using an analysis of variance and if the treatment had a significant effect, it was followed by a Duncan Multiple Range Test (DMRT). The results showed that the effect of time had a very significant effect on total rendement, L' value (brightness), b' value (green-yellow), protein content, water absorption capacity, swelling power, solubility of germinated waxy corn flour. This research also resulting a significant effect on moisture content and carbohydrate content, but resulting a nonsignificant effect on bulk density, a' value (blue-red), ash content, fat content, crude fiber content and oil absorption capacity. The best characteristic of the flour in this study was the waxy corn flour that has been germinated for 48 hours with $79.44 \%$ rendement, $0.50 \mathrm{~g} / \mathrm{ml}$ bulk density, L':54.34, a': 6.90, b': 22,89 color, $7.15 \%$ water content, $1.56 \%$ ash content, $6.36 \%$ fat content, $9.66 \%$ protein content, $82.31 \%$ carbohydrates content, $2.39 \%$ fiber content, $1.55 \mathrm{ml} / \mathrm{g}$ water absorption, $1.81 \mathrm{ml} / \mathrm{g}$ oil absorption, $6.70 \mathrm{~g} / \mathrm{g}$ swelling power, and $51.72 \%$ solubility.
\end{abstract}

Keywords : germinated waxy corn flour, germination time, waxy corn, Zea mays ceratina L

\section{PENDAHULUAN}

Jagung pulut (Zea mays ceratina $\mathrm{L}$.)

adalah salah satu jenis jagung yang tumbuh di Indonesia yang dikenal juga sebagai jagung ketan (waxy corn) oleh masyarakat umum. Jagung pulut merupakan pangan lokal yang memiliki nutrisi memadai sehingga berpeluang untuk dikembangkan serta dapat mendukung diversifikasi dan industri pangan (Suarni et al., 2019). Hal tersebut sesuai dengan kebijakan pemerintah mengenai pemanfaatan pangan lokal untuk menjaga ketahanan pangan yang dinilai tepat karena jagung pulut tersedia dalam jumlah cukup dan mudah dikembangkan di daerah setempat. Pemanfaatan jagung pulut saat ini bila dibandingkan dengan jagung lokal kuning dan jagung manis masih relatif lebih rendah. Palijama et al. (2020) menyatakan bahwa pada umumnya jagung pulut hanya diolah oleh masyarakat secara tradisional, yaitu dengan cara dibakar, direbus atau dikeringkan untuk pakan ternak. Untuk meningkatkan pemanfaatan jagung pulut yang lebih luas, praktis dan 
efektif dapat dilakukan perkecambahan serta pengolahan lebih lanjut menjadi produk intermediate.

Dalam pengolahan pangan, karakteristik fungsional teknis merupakan hal yang penting bagi konsumen dalam menentukan kegunaan suatu produk. Perkecambahan merupakan salah satu upaya yang mudah dan murah untuk dilakukan dalam meningkatkan karakteristik fungsional teknis jagung pulut. Penelitian Adedeji et al. (2019) mengenai penggunaan tepung kecambah jagung sebagai bahan pembuatan cookies menyatakan bahwa lama perkecambahan selama 0, 24, 48 dan 72 jam memiliki pengaruh yang signifikan terhadap daya serap air, daya serap minyak, dan swelling power tepung kecambah jagung. Tidak hanya karakteristik fungsional yang meningkat, metode perkecambahan juga dapat meningkatkan kandungan gizi pada bahan pangan seperti protein dan serat yang berguna bagi kesehatan. Berdasarkan hasil penelitian Lombu et al. (2018) tepung kecambah jagung varietas Arjuna memiliki kandungan protein dan serat yang lebih tinggi bila dibandingkan dengan tepung jagung tanpa perkecambahan. Berdasarkan beberapa penelitian yang telah dilakukan, waktu merupakan perlakuan yang penting sehingga pada penelitian ini diberikan perlakuan waktu pada perkecambahan jagung pulut.

Kecambah jagung merupakan bahan pangan yang sulit untuk diaplikasikan kedalam berbagai pangan olahan. Untuk meningkatkan pemanfaatan yang lebih praktis dan efektif perlu dilakukan pengolahan kecambah jagung pulut menjadi produk intermediate. Salah satu upaya yang dapat meningkatkan pemanfaatan kecambah jagung pulut yaitu mengolahnya menjadi tepung. Pengolahan kecambah menjadi tepung juga dapat memperpanjang umur simpan bahan tersebut (Wisaniyasa dan Suter, 2016 dalam Wisaniyasa et al., 2017). Tepung kecambah jagung pulut merupakan bahan pangan yang perlu diteliti karakteristik fisik, kimia dan sifat fungsionalnya agar dapat diketahui kandungan gizi, kegunaan, serta cara penyimpananya. Berdasarkan latar belakang tersebut, perlu dilakukan penelitian untuk mengetahui sifat fisik, kimia dan fungsional pada tepung kecambah jagung pulut berdasarkan lama waktu perkecambahanya.

\section{METODE PENELITIAN}

\section{Tempat dan Waktu Penelitian}

Penelitian ini dilakukan di Laboratorium Pengolahan Pangan dan Laboratorium Analisis pangan Fakultas Teknologi Pertanian Universitas Udayana Jl. P. B. Sudirman, Denpasar. Pelaksanaan penelitian ini dilakukan pada bulan Februari 2020 sampai April 2020.

\section{Bahan dan Alat}

Bahan yang digunakan dalam penelitian ini, antara lain : Biji jagung pulut (pipilan kering) varietas F1 yang diperoleh 
di desa Gelgel, Klungkung, Bali, daun pisang, aquades, air, $\mathrm{H}_{2} \mathrm{SO}_{4}$ pekat, $\mathrm{NaOH}$, Indikator PP, Asam borat 3\%, $\mathrm{HCl}, \mathrm{K}_{2} \mathrm{SO}_{4}$, larutan heksana dan minyak kelapa.

Alat yang digunakan dalam penelitian ini adalah keranjang plastik berlubang $30 \mathrm{x}$ $24 \mathrm{~cm}$, timbangan analitik (Shimadzu ATY224), botol spray, wadah baskom, ayakan 60 mesh, kuas, cawan aluminium, cawan porselin, oven, desikator, pinset, soxhlet, labu lemak, vaseline, benang wol, kertas saring, kertas whatman 42, tabung reaksi (pyrex), tabung sentrifius, gelas ukur (pyrex), labu erlenmeyer (pyrex), pipet tetes (pyrex), pipet volume (pyrex), rak tabung, vortex, labu takar (pyrex), buret, statif, pemanas listrik, corong plastik, gelas plastik, vortex, cawan petri, kaca arloji, colorimeter PCE-CSM 4, spatula, aluminium foil, waterbath dan sentrifius.

\section{Rancangan Penelitian dan Analisa Data}

Rancangan yang digunakan dalam penelitian ini yaitu Rancangan Acak Lengkap (RAL) dengan perlakuan lama perkecambahan 0 jam, 24 jam, 36 jam dan 48 jam. Masing - masing perlakuan diulang sebanyak 4 kali sehingga dihasilkan 16 unit percobaan. Data yang diperoleh kemudian dianalisis dengan sidik ragam dan apabila terdapat pengaruh perlakuan dilanjutkan dengan uji Duncan (Gomez and Gomez, 1995).

\section{Pelaksanaan Penelitian.}

Pelaksanaan penelitian meliputi beberapa tahap, yaitu :

\section{Persiapan Bahan}

Tahap awal pada penelitian ini dimulai dengan persiapan bahan. Bahan utama yang disiapkan adalah biji jagung pulut pipilan kering. Biji jagung pulut direndam dalam air pada suhu ruang selama 12 jam dengan perbandingan air dan biji jagung 2 : 1 hingga seluruh permukaan jagung terendam (Narsih et al., 2018). Setelah perendaman, bahan dicuci menggunakan air mengalir lalu ditiriskan.

\section{Perkecambahan Biji Jagung Pulut}

Biji yang telah direndam selama 12 jam kemudian dikecambahkan selama 0, 24, 36 dan 48 jam. Perkecambahan dilakukan dengan menggunakan alas dan penutup daun pisang pada wadah plastik berlubang agar udara dapat memasuki media perkecambahan. Penggunaan alas dan tutup daun pisang tersebut bertujuan untuk menjaga kelembaban dari biji jagung, sementara penggunaan wadah plastik berlubang yaitu untuk membuat jagung tetap terpapar udara agar biji jagung tetap berespirasi. Biji yang dikecambahkan kemudian diperciki air sebanyak $10 \mathrm{ml}$ jsetiap 12 jam karena biji jagung memerlukan kelembaban dan membutuhkan air untuk proses metabolisme. Kecambah yang dihasilkan kemudian disimpan dalam wadah plastik.

\section{Pembuatan Tepung Kecambah Jagung Pulut}

Kecambah jagung pulut yang dihasilkan dikeringkan menggunakan oven 
dengan suhu $50^{\circ} \mathrm{C}$ selama 20 jam (Lombu et al., 2018). Setelah dikeringkan, kecambah dihaluskan menggunakan blender lalu diayak dengan ayakan 60 mesh untuk menghasilkan butiran tepung yang homogen (Putra, 2008). Diagram alir proses pembuatan tepung kecambah jagung pulut dapat dilihat pada Gambar 2.

\section{Parameter yang diamati}

Parameter yang diamati dalam penelitian ini adalah densitas kamba (Muchtadi et al., 1993 dalam Anita, 2009), derajat warna dengan menggunakan alat Colorimeter PCE-CSM 4 (Weaver, 1996 dalam Lestari et al., 2019), kadar air dengan metode pengeringan (Anonimous, 1992), kadar abu dengan metode pengabuan (Faridah et al., 2008), kadar lemak dengan metode Soxhlet (AOAC, 1995), kadar protein dengan metode Kjeldahl
(Sudarmadji et al., 1997), kadar karbohidrat by different (Faridah et al., 2008), kadar serat kasar dengan metode hidrolisis asambasa (Sudarmadji et al., 1997), daya serap air dengan metode gravimetri (Lin et al., 1974), daya serap minyak dengan metode gravimetri (Soluski dan Fleming, 1977 dalam Budjianto et al., 2011), swelling power dengan metode gravimetri (Senanyake et al., 2013 dalam Parwiyanti et al., 2015), dan kelarutan dengan metode gravimetri (Senanyake et al., 2013 dalam Parwiyanti et al., 2015).

\section{HASIL DAN PEMBAHASAN}

\section{Karakteristik Fisik}

Hasil analisis karakteristik fisik yang meliputi densitas kamba, warna $\mathrm{L}$, a dan $\mathrm{b}$ tepung kecambah jagung pulut dapat dilihat pada Tabel 1.

Tabel 1. Nilai rata-rata hasil analisis karakteristik fisik tepung kecambah jagung pulut

\begin{tabular}{ccccc}
\hline \multirow{2}{*}{ Lama Perkecambahan } & \multicolumn{4}{c}{ Parameter Uji } \\
\cline { 2 - 5 } & Densitas & \multicolumn{3}{c}{ Warna } \\
\cline { 3 - 5 } & Kamba (g/ml) & L & a & b \\
\hline 0 Jam & $0,49 \pm 0,0023$ a & $61,01 \pm 0,25$ a & $6,62 \pm 0,15$ a & $21,68 \pm 0,47 \mathrm{c}$ \\
24 Jam & $0,49 \pm 0,0053$ a & $58,73 \pm 0,32 \mathrm{~b}$ & $6,67 \pm 0,04$ a & $21,98 \pm 0,16 \mathrm{c}$ \\
36 Jam & $0,49 \pm 0,0041$ a & $55,55 \pm 0,77$ c & $6,77 \pm 0,22$ a & $22,45 \pm 0,11$ b \\
48 Jam & $0,50 \pm 0,0032$ a & $54,34 \pm 0,17$ d & $6,90 \pm 0,14$ a & $22,89 \pm 0,05$ a \\
\hline
\end{tabular}

Keterangan: Nilai rata-rata yang diikuti oleh huruf yang berbeda pada kolom yang sama menunjukan perlakuan yang berbeda nyata $(\mathrm{P}<0,05)$

\section{Densitas Kamba}

Hasil sidik ragam menunjukan bahwa lama perkecambahan berpengaruh tidak nyata $(\mathrm{P}>0,05)$ terhadap densitas kamba tepung kecambah jagung pulut. Data yang tersaji pada Tabel 1 menunjukan bahwa densitas kamba tepung kecambah jagung pulut berkisar antara $0,49 \mathrm{~g} / \mathrm{ml}$ hingga $0,50 \mathrm{~g} / \mathrm{ml}$. 


\section{Warna}

Hasil sidik ragam menunjukan bahwa lama perkecambahan berpengaruh sangat nyata $(\mathrm{P}<0,01)$ terhadap nilai $\mathrm{L}$ yang mengindikasikan warna tingkat kecerahan tepung kecambah jagung pulut serta nilai $b$ yang mengindikasikan warna biru-kuning. Berdasarkan hasil sidik ragam lama perkecambahan berpengaruh tidak nyata $(\mathrm{P}>0,05)$ terhadap nilai a yang mengindikasikan warna hijau-merah tepung kecambah jagung pulut. Hasil analisis warna tepung kecambah jagung pulut dapat dilihat pada Tabel 1. Penurunan tingkat kecerahan dan peningkatan warna kuning tepung kecambah jagung pulut seiring lama perkecambahan terjadi karena adanya reaksi pencokelatan non enzimatis, yaitu reaksi Maillard. Verma et al. (2019) menyatakan bahwa reaksi Maillard merupakan reaksi pencokelatan non-enzimatis antara gula pereduksi dan asam amino yang terjadi karena pemanasan dan penyimpanan. Menurut Ai dan Ballo (2010) proses perkecambahan akan menyebabkan enzim aktif bekerja, sehingga dihasilkan senyawasenyawa sederhana seperti maltosa, glukosa dan asam amino. Meningkatnya kandungan asam amino dan maltosa serta glukosa yang merupakan gula pereduksi seiring lama perkecambahan akan menyebabkan terjadinya tahapan reaksi Maillard. Adanya panas pengovenan dengan suhu $50^{\circ} \mathrm{C}$ serta waktu pengovenan yang cukup lama yaitu 20 jam memungkinkan reaksi Maillard terjadi sehingga tepung kecambah jagung pulut mengalami penurunan tingkat kecerahan dan peningkatan warna kuning.

\section{Karakteristik Kimia}

Hasil analisis karakteristik kimia yang meliputi kadar air, kadar abu, kadar lemak, kadar protein, kadar karbohidrat dan kadar serat tepung kecambah jagung pulut dapat dilihat pada Tabel 2.

\section{Kadar Air}

Hasil sidik ragam menunjukan bahwa lama perkecambahan berpengaruh nyata $(\mathrm{P}<0,05)$ terhadap kadar air tepung kecambah jagung pulut. Hasil pengujian kadar air dari Tabel 2 menunjukan bahwa kadar air tertinggi terdapat pada lama perkecambahan 24 jam yaitu $8,22 \%$ dan kadar air terendah terdapat pada lama perkecambahan 48 jam yaitu $7,15 \%$. Tingginya kadar air pada lama perkecambahan 24 jam terjadi karena biji jagung masih menyerap air yang dipercikan dalam proses perkecambahan. Penurunan kadar air yang terjadi pada lama perkecambahan 36 jam disebabkan oleh tingginya aktivitas enzim amilase pada waktu perkecambahan tersebut. Menurut Bahri et al., (2012) aktivitas enzim amilase tertinggi pada perkecambahan jagung ketan terjadi pada lama perkecambahan 36 jam. Meningkatnya aktivitas enzim amilase akan menyebabkan pati yang terhidrolisis semakin banyak, sehingga kandungan air pada bahan akan semakin menurun karena air digunakan untuk memisahkan ikatan pati. 
Perbedaan morfologi biji jagung juga memungkinkan terjadinya penurunan kadar air karena memiliki hubungan dengan laju penguapan air pada proses pengovenan. Biji jagung pulut yang dikecambahkan selama 0 dan 24 jam masih memiliki bentuk biji jagung yang lebih utuh, sedangkan jagung yang dikecambahkan selama 36 dan 48 jam sudah mengalami kemunculan plumula. Munculnya plumula pada biji jagung pulut akan menyebabkan jaringan perikarp yang membungkus endosperm jagung pulut terbuka sehingga membuat air lebih mudah menguap saat proses pengovenan.

Tabel 2. Nilai rata-rata hasil analisis karakteristik kimia tepung kecambah jagung pulut.

\begin{tabular}{|c|c|c|c|c|c|c|}
\hline \multirow[b]{2}{*}{$\begin{array}{c}\text { Lama } \\
\text { Perkecambahan }\end{array}$} & \multicolumn{6}{|c|}{ Parameter Uji } \\
\hline & $\begin{array}{c}\text { Kadar } \\
\text { Air } \\
(\% \text { bb })\end{array}$ & $\begin{array}{c}\text { Kadar } \\
\text { Abu } \\
(\% \text { bk })\end{array}$ & $\begin{array}{l}\text { Kadar } \\
\text { Lemak } \\
(\% \text { bk })\end{array}$ & $\begin{array}{l}\text { Kadar } \\
\text { Protein } \\
(\% \text { bk })\end{array}$ & $\begin{array}{c}\text { Kadar } \\
\text { Karbohidrat } \\
(\% \text { bk })\end{array}$ & $\begin{array}{l}\text { Kadar } \\
\text { Serat } \\
\text { Kasar } \\
\text { (\%bk) }\end{array}$ \\
\hline $0 \mathrm{Jam}$ & $\begin{array}{r}7,88 \pm \\
0,36 \mathrm{ab}\end{array}$ & $\begin{array}{l}1,64 \pm \\
0,09 \mathrm{a}\end{array}$ & $\begin{array}{l}6,80 \pm \\
0,34 \mathrm{a}\end{array}$ & $\begin{array}{l}8,38 \pm \\
0,69 \mathrm{~b}\end{array}$ & $\begin{array}{c}83,18 \pm \\
0,66 \mathrm{a}\end{array}$ & $\begin{array}{l}1,93 \pm \\
0,35 \mathrm{a}\end{array}$ \\
\hline 24 Jam & $\begin{array}{l}8,22 \pm \\
0,76 \mathrm{a}\end{array}$ & $\begin{array}{l}1,67 \pm \\
0,22 \mathrm{a}\end{array}$ & $\begin{array}{l}6,81 \pm \\
0,27 \mathrm{a}\end{array}$ & $\begin{array}{l}8,45 \pm \\
0,13 \mathrm{~b}\end{array}$ & $\begin{array}{c}83,07 \pm \\
0,28 \mathrm{a}\end{array}$ & $\begin{array}{l}1,96 \pm \\
0,21 \mathrm{a}\end{array}$ \\
\hline $36 \mathrm{Jam}$ & $\begin{array}{l}7,39 \pm \\
0,36 \mathrm{~b}\end{array}$ & $\begin{array}{l}1,65 \pm \\
0,09 \mathrm{a}\end{array}$ & $\begin{array}{l}6,48 \pm \\
0,44 a\end{array}$ & $\begin{array}{l}9,07 \pm \\
0,22 \mathrm{a}\end{array}$ & $\begin{array}{l}82,80 \pm \\
0,31 \mathrm{ab}\end{array}$ & $\begin{array}{l}2,35 \pm \\
0,58 \mathrm{a}\end{array}$ \\
\hline $48 \mathrm{Jam}$ & $\begin{array}{l}7,15 \pm \\
0,16 \mathrm{~b}\end{array}$ & $\begin{array}{l}1,66 \pm \\
0,12 \mathrm{a}\end{array}$ & $\begin{array}{l}6,36 \pm \\
0,36 \mathrm{a}\end{array}$ & $\begin{array}{l}9,66 \pm \\
0,23 \mathrm{a}\end{array}$ & $\begin{array}{c}82,31 \pm \\
0,20 \mathrm{~b}\end{array}$ & $\begin{array}{l}2,39 \pm \\
0,24 \mathrm{a}\end{array}$ \\
\hline
\end{tabular}

Keterangan : Nilai rata-rata yang diikuti oleh huruf yang berbeda pada kolom yang sama menunjukan perlakuan yang berbeda nyata $(\mathrm{P}<0,05)$.

\section{Kadar Abu}

Hasil sidik ragam menunjukan bahwa lama perkecambahan berpengaruh tidak nyata $(\mathrm{P}>0,05)$ terhadap kadar abu tepung kecambah jagung pulut. Tabel 2 menunjukan bahwa kadar abu tepung kecambah jagung pulut berkisar antara $1,64 \%$ hingga $1,66 \%$.

\section{Kadar Lemak}

Hasil sidik ragam menunjukan bahwa lama perkecambahan berpengaruh tidak nyata $(\mathrm{P}>0,05)$ terhadap kandungan lemak tepung kecambah jagung pulut. Berdasarkan data dari Tabel 2, kadar lemak tepung kecambah jagung pulut berkisar antara $6,36 \%$ hingga $6,80 \%$.

\section{Kadar Protein}

Hasil sidik ragam menunjukan bahwa lama perkecambahan berpengaruh sangat nyata $(\mathrm{P}<0,01)$ terhadap kandungan protein yang terdapat pada tepung kecambah jagung pulut. Peningkatan kandungan protein 
terjadi karena adanya sintesis asam amino yang terjadi seiring lama perkecambahan. Hal tersebut didukung oleh pernyataan Dewi et al., (2018) yang menyatakan bahwa pada proses perkecambahan asam amino yang merupakan penyusun dari protein akan terbentuk. Asam amino yang telah tersintesis berfungsi sebagai bahan yang dibutuhkan dalam proses sintesa protein. Selama perkecambahan akan terjadi proses sintesa protein karena protein merupakan komponen nutrisi yang dibutuhkan kecambah untuk bertumbuh. Hasil penelitian serupa juga ditemukan pada penelitian Ferdiawan et al., (2019) yang menyatakan peningkatan kandungan protein pada kecambah terjadi karena adanya sintesis asam-asam amino essensial yang dan dibutuhkan dalam proses pertumbuhan. Menurut Ai dan Ballo (2010) salah satu tahapan yang terjadi pada proses perkecambahan yaitu sekresi enzim. Peningkatan jumlah enzim juga dapat meningkatkan kandungan protein pada tepung kecambah jagung pulut. Hal tersebut didukung oleh pernyataan Trismilah dan Budiasih (2009) yang menyatakan bahwa enzim merupakan protein yang terdiri dari asam amino dalam komposisi dan susunan rantai yang teratur dan tetap.

\section{Kadar Karbohidrat}

Hasil sidik ragam menunjukan bahwa lama perkecambahan berpengaruh nyata $(\mathrm{P}>0,05)$ terhadap kandungan karbohidrat tepung kecambah jagung pulut. Berdasarkan data dari Tabel 2, kandungan karbohidrat akan semakin menurun seiring lama perkecambahan. Seiring lama perkecambahan kandungan amilosa dan amilopektin didegradasi oleh enzim menjadi beberapa molekul karbohidrat yang lebih sederhana, salah satunya adalah glukosa. Penggunaan glukosa sebagai sumber energi utama untuk berkecambah menyebabkan menurunya kandungan karbohidrat. Hal tersebut didukung oleh pernyataan Lombu et al. (2019) yang menyatakan karbohidrat sebagai persediaan makanan didegradasi oleh enzim $\alpha$-amilase dan $\beta$-amilase menjadi molekul sederhana yang nantinya akan diubah lagi menjadi energi. Meningkatnya kandungan nutrisi lain seperti protein yang terjadi selama perkecambahan juga dapat mempengaruhi kadar karbohidrat. Kadar protein yang semakin meningkat akan menyebabkan penurunan proporsi karbohidrat yang terdapat pada tepung kecambah jagung pulut.

\section{Kadar Serat Kasar}

Hasil sidik ragam menunjukan lama perkecambahan berpengaruh tidak nyata $(\mathrm{P}>0,05)$ terhadap kandungan serat kasar tepung kecambah jagung pulut. Berdasarkan data dari Tabel 2, kadar serat kasar tepung kecambah jagung pulut berkisar antara $1,93 \%$ hingga $2,39 \%$.

\section{Karakteristik Fungsional}

Hasil analisis karakteristik fungsional tepung kecambah jagung pulut yang 
meliputi daya serap air, daya serap minyak, swelling power, dan kelarutan dapat dilihat pada Tabel 3.

Tabel 3. Nilai rata-rata karakteristik fungsional tepung kecambah jagung pulut.

\begin{tabular}{ccccc}
\hline \multirow{2}{*}{$\begin{array}{c}\text { Lama } \\
\text { Perkecambahan }\end{array}$} & $\begin{array}{c}\text { Daya Serap } \\
\text { Air } \\
(\mathbf{m l} / \mathbf{g})\end{array}$ & $\begin{array}{c}\text { Daya Serap } \\
\text { Minyak } \\
(\mathbf{m l} / \mathbf{g})\end{array}$ & $\begin{array}{c}\text { Swelling Power } \\
(\mathbf{g} / \mathbf{g})\end{array}$ & $\begin{array}{c}\text { Kelarutan } \\
(\boldsymbol{\%})\end{array}$ \\
\hline 0 Jam & $1,34 \pm 0,01 \mathrm{c}$ & $1,91 \pm 0,10 \mathrm{a}$ & $13,38 \pm 1,51 \mathrm{a}$ & $11,85 \pm 2,81 \mathrm{~d}$ \\
24 Jam & $1,35 \pm 0,04 \mathrm{c}$ & $1,91 \pm 0,02 \mathrm{a}$ & $12,80 \pm 0,89 \mathrm{a}$ & $19,24 \pm 1,79 \mathrm{c}$ \\
36 Jam & $1,45 \pm 0,04 \mathrm{~b}$ & $1,86 \pm 0,21 \mathrm{a}$ & $8,34 \pm 0,79 \mathrm{~b}$ & $41,49 \pm 1,88 \mathrm{~b}$ \\
48 Jam & $1,55 \pm 0,05 \mathrm{a}$ & $1,81 \pm 0,10 \mathrm{a}$ & $6,70 \pm 0,26 \mathrm{c}$ & $51,72 \pm 3,32 \mathrm{a}$ \\
\hline
\end{tabular}

Keterangan : Nilai rata-rata yang diikuti oleh huruf yang berbeda pada kolom yang sama menunjukan perlakuan yang berbeda nyata $(\mathrm{P}<0,05)$.

\section{Daya Serap Air}

Hasil sidik ragam menunjukan bahwa lama perkecambahan berpengaruh sangat nyata $(\mathrm{P}<0,01)$ terhadap daya serap air tepung kecambah jagung pulut. Daya serap air yang meningkat pada proses perkecambahan kemungkinan terjadi karena seiring lama perkecambahan maka akan terbentuk senyawa-senyawa yang memiliki kemampuan menyerap air. Menurut Adedeji et al. (2014) dalam Liadi (2019) peningkatan daya serap air kemungkinan terjadi karena perkecambahan menghasilkan senyawa yang memiliki kapasitas penyerapan air yang baik seperti gula larut. Peningkatan protein pada proses perkecambahan jagung pulut juga turut mempengaruhi kemampuan tepung untuk menyerap air. Hal tersebut didukung oleh pernyataan Astawan dan Hazmi (2016) yang menyatakan bahwa protein berperan dalam kemampuan bahan pangan untuk mengikat air dikarenakan protein memiliki gugus yang bersifat hidrofilik (mudah menyerap air).

\section{Daya Serap Minyak}

Hasil sidik ragam menunjukan bahwa lama perkecambahan berpengaruh tidak nyata $(\mathrm{P}>0,05)$ terhadap daya serap minyak tepung kecambah jagung pulut. Berdasarkan data dari Tabel 3, daya serap minyak tepung kecambah jagung pulut berkisar antara $1,81 \%$ hingga $1,91 \%$.

\section{Swelling Power}

Hasil sidik ragam menunjukan bahwa lama perkecambahan berpengaruh sangat nyata $(\mathrm{P}<0,01)$ terhadap swelling power tepung kecambah jagung pulut. Degradasi pati pada proses perkecambahan diduga menjadi penyebab penurunan swelling power pada tepung kecambah jagung pulut. 
Hal tersebut dikarenakan pati merupakan sumber energi utama yang dibutuhkan untuk perkecambahan dan terdiri dari 2 molekul, yaitu amilosa dan amilopektin. Menurut Mahendra et al (2019) proses perkecambahan akan menyebabkan perombakan makromolekul menjadi gula sederhana sehingga menyebabkan penurunan kandungan amilosa dan amilopektin. Seiring lama perkecambahan maka swelling power tepung kecambah jagung pulut akan semakin menurun karena menurunya kandungan amilosa dan amilopektin tersebut. Adedeji et al. (2014) juga menyatakan bahwa penurunan swelling power yang terjadi seiring lama perkecambahan jagung dikarenakan adanya aktivitas enzim amilase yang menyebabkan terhidrolisisnya pati.

\section{Kelarutan}

Hasil sidik ragam menunjukan bahwa lama perkecambahan berpengaruh sangat nyata $(\mathrm{P}<0,01)$ terhadap kelarutan tepung kecambah jagung pulut. Peningkatan kelarutan pada tepung kecambah jagung pulut diduga terjadi karena terdegradasinya molekul pati menjadi gula-gula sederhana yang larut air. Hal tersebut didukung oleh penelitian Damayanti et al. (2019) yang menyatakan enzim $\alpha$-amilase mengalami peningkatan dan menghidrolisis amilosa dan amilopektin menjadi dekstrin dan maltosa yang merupakan gula larut.

\section{KESIMPULAN}

Lama perkecambahan berpengaruh sangat nyata terhadap nilai L (tingkat kecerahan), nilai b (warna biru-kuning), kadar protein, daya serap air, swelling power, dan kelarutan tepung kecambah jagung pulut. Lama perkecambahan berpengaruh nyata terhadap kadar air dan kadar karbohidrat namun berpengaruh tidak nyata terhadap densitas kamba, nilai a (warna hijau-merah), kadar abu, kadar lemak, kadar serat dan daya serap minyak tepung kecambah jagung pulut. Tepung kecambah jagung terbaik dihasilkan pada lama perkecambahan 48 jam dengan karakteristik densitas kamba 0,50 g/ml, warna L': 54,34, warna a': 6,90, warna b': 22,89, kadar air 7,15\%, kadar abu 1,66\%, kadar lemak 6,36\%, kadar protein 9,66\%, kadar karbohidrat $82,31 \%$, kadar serat kasar $2,38 \%$, daya serap air $1,55 \mathrm{ml} / \mathrm{g}$, daya serap minyak $1,81 \mathrm{ml} / \mathrm{g}$, swelling power $6,70 \mathrm{~g} / \mathrm{g}$, dan kelarutan 51,72\%.

\section{DAFTAR PUSTAKA}

Adedeji, O. E., O.D. Oyinloye, dan O.B. Ocheme, 2014. Effects of Germination Time on the Functional

Properties of Maize Flour and the Degree of Gelatinization of Its Cookies. Afr. Journal of Food Science. 8(1) :42-47.

Anita, S. 2009. Studi Sifat Fisikokimia Sifat Fungsional Karbohidrat Dan Aktivitas Antioksidan Tepung Kecambah Kacang Komak (Lablab purpureus (L) sweet) [skripsi]. Institut Pertanian Bogor, Bogor.

Ai, N. S., dan M. Ballo. 2010. Peranan Air dalam Perkecambahan Biji. Jurnal Ilmiah Sains Vol. 10(2): 190-195. 
Astawan, M. dan H. Khaidar. 2016. Karakteristik Fisikokimia Tepung Kecambah Kedelai. Jurnal Pangan, Vol 25(2): 105-112.

AOAC. 1995. Official Methods of Analysis. Washington: Association of Official Analytical Chemists.

Bahri, S., M. Mirzan, M. Hasan. 2012. Karakterisasi Enzim Amilase dari Kecambah Biji Jagung Ketan (Zea mays ceratina L.). Jurnal Natural Science Vol. 1.(1) 132-143.

Damayanti , I.D.A.B., N.W. Wisaniyasa, I.W.R. Widarta. Studi Sifat Fisik, Kimia, Fungsional, Dan Kadar Asam Sianida Tepung Kecambah Kacang Koro Pedang (Canavalia ensiformis L.). Jurnal Ilmu dan Teknologi Pangan vol 8(3): 238-247.

Dewi, I.G.A.A.S.P., I.G.A. Ekawati dan I.D.P.K. Pratiwi. 2018. Pengaruh Lama Perkecambahan Millet (Panicum milliaceum) Terhadap Karakteristik Flakes. Jurnal Ilmu dan Teknologi Pangan. Vol. 7(4): 175-183.

Faridah, D.N., F. Kusnandar, D. Herawati, H.D. Kusumaningrum, N. Wulandari. 2008. Penuntun Praktikum Analisis Pangan. Departemen Ilmu dan Teknologi Pangan. Fakultas Teknologi Pertanian IPB, Bogor.

Ferdiawan, N., Nurwantoro, dan B. Dwiloka. 2019. Pengaruh Lama Waktu Germinasi terhadap Sifat Fisik dan Sifat Kimia Tepung Kacang Tolo (Vigna unguiculata L). Jurnal Teknologi Pangan Vol 3 (2): 349-354.

Gomez, K. A. dan A. A. Gomez. 1995. Prosedur Statistik untuk Penelitian Pertanian (Terjemahan). E. Syamsudin dan J. S. Baharsjah. UI Press. Jakarta. 698 hal.

Lestari, P.D.A., L.P. Wrasiati, N.P. Suwariani. 2019. Karakteristrik Enkapsulat Ekstrak Pewarna Fungsional Bunga Rosella (Hibiscus sabdariffa L.) pada Perlakuan Perbandingan Kasein-Maltodekstrin. Jurnal Rekayasa dan Manajemen Agroindustri. Vol 7(4):509-520.

Liadi, V. C., N. W. Wisaniyasa, N. N.Puspawati. 2019. Studi Sifat Fungsional dan Kimia Tepung
Kecambah Kacang Koro Benguk (Mucuna puriens L.). Jurnal Ilmu dan Teknologi Pangan. Vol. 8(2): 131-139.

Lin, M.Y., G.S. Humbert and F.W. Soluski. 1974. Certain Functional Properties of Sunflower Meal Products. J. Food Sci. 39:368.

Lombu, W. K., N. W. Wisaniyasa dan A.A.I.S Wiadyani. 2018. Perbedaan Karakteristik Kimia dan Daya Cerna Pati Tepung Jagung dan Tepung Kecambah Jagung. Jurnal ITEPA Vol. 7(1): 43- 51.

Mahendra, P. E. D., N. L. A. Yusasrini, I. D. P. K. Pratiwi. 2019. Pengaruh Metode Pengolahan Terhadap Kandungan Tanin dan Sifat Fungsional Tepung Proso Millet (Panicum Miliaceum). Jurnal Ilmu dan Teknologi Pangan. Vol. 8(4): 354-367.

Muchtadi, D. 2009. Pengantar Ilmu Gizi. Alfabeta. Bandung.

Narsih., Agato, R. Sesario. 2018. Penurunan Senyawa Antinutrisi pada Biji Jagung dengan Berbagai Metoda. Jurnal Teknologi Pangan Vol 9(1): 45-50.

Palijama, S., R. Breemer, dan M. Topurmera. 2020. Karakteristik Kimia dan Fisik Bubur Instan Berbahan Dasar Tepung Jagung Pulut dan Tepung Kacang Merah. Jurnal Agritekno. Vol 9(1): 20-27.

Parwiyanti, F. Pratama, A. Wijaya, N. Malahayati, dan E. Lidiasari. Swelling Power dan Kelarutan Pati Ganyong (Canna edulis Kerr.) Termodifikasi Melalui Heat Moisture Treatment dan Penambahan Gum Xanthan Untuk Produk Roti. Prosiding Seminar Hasil Penelitian Tanaman Aneka Kacang dan Umbi 2015, 692-699.

Putra, I.A., Hanum, H., dan Hanum.C, 2010. Pengelolaan Hara Kalium Berdasarkan Batas Kritis Untuk Tanaman Jagung (Zea mays L.) Pada Berbagai Status Hara di Tanah Inceptisol. Tesis Pasca Sarjana Prodi Agroekoteknologi.

Senanayake, S., Gunaratne, A., Ranawera, K.K.D.S., dan Bamunuarachchi, A., 2013. Effect of heat moisture treatment conditions on swelling power and water soluble index of 
different cultivars of sweet patato (Ipomea Batatas (L). Lam) starch. ISRN Agronomy. Hindawi Publishing Corporation 1-4.

Soluski F., Fleming S. E. 1977. Chemical, Functional, and Nutritional Properties of Sunflower Protein Products. Journal of the American Oil Chemist's Society. Vol. 54(2) : 100-104.

Suarni, Muh. A., dan Herman S. 2019. Potensi Pengembangan Jagung Pulut Mendukung Diversifikasi Pangan. Jurnal Litbang Pertanian. Vol. 39(1) $: 1-12$.

Sudarmadji S., Bambang H., dan Suhardi. 1997. Prosedur Analisa untuk Bahan Makanan dan Pertanian. Liberty. Yogyakarta.

Trismilah dan B. Wahyuntari. 2009. Pemanfaatan Berbagai Jenis Pati sebagai Sumber Karbon untuk Produksi alfa-Amilase Ekstraseluler Bacillus sp $\mathrm{SW}_{2}$. Jurnal Sains dan
Teknologi Indonesia, $\quad$ Vol 11(3): 169-174.

Verma, V., Z. Singh, dan N. Yadav. 2019. Research Trends in Food Technology and Nutrition. AkiNik Publications: New Delhi.

Wisaniyasa, N. W., dan I. K. Suter. 2016. Kajian Sifat Fungsional dan Kimia Tepung Kecambah Kacang Merah (Phaseolus vulgaris. L). Media Ilmiah Teknologi Pangan. Vol. 3(1): 26-34.

Wisaniyasa, N. W., A. S. Duniaji, dan A. A. G. N. Anom Jambe. 2017. Studi Daya Cerna Protein, Aktivitas Antioksidan dan Sifat Fungsional Tepung Kecambah Kacang Merah (Phaseolus vulgaris L.) dalam Rangka Pengembangan Pangan Fungsional. Media Imliah Teknologi Pangan. Vol.4(2): 120-126.

Weaver, C. 1996. The Food Chemistry Laboratory. CRC Press: Florida. 